\title{
Impulsivity, "Advergames," and Food Intake
}

Citation for published version (APA):

Folkvord, F., Anschutz, D. J., Nederkoorn, C., Westerik, H., \& Buijzen, M. (2014). Impulsivity,

"Advergames," and Food Intake. Pediatrics, 133(6), 1007-1012. https://doi.org/10.1542/peds.2013-3384

Document status and date:

Published: 01/06/2014

DOI:

10.1542/peds.2013-3384

Document Version:

Publisher's PDF, also known as Version of record

\section{Document license:}

Taverne

\section{Please check the document version of this publication:}

- A submitted manuscript is the version of the article upon submission and before peer-review. There can be important differences between the submitted version and the official published version of record.

People interested in the research are advised to contact the author for the final version of the publication, or visit the DOI to the publisher's website.

- The final author version and the galley proof are versions of the publication after peer review.

- The final published version features the final layout of the paper including the volume, issue and page numbers.

Link to publication

\footnotetext{
General rights rights.

- You may freely distribute the URL identifying the publication in the public portal. please follow below link for the End User Agreement:

www.umlib.nl/taverne-license

Take down policy

If you believe that this document breaches copyright please contact us at:

repository@maastrichtuniversity.nl

providing details and we will investigate your claim.
}

Copyright and moral rights for the publications made accessible in the public portal are retained by the authors and/or other copyright owners and it is a condition of accessing publications that users recognise and abide by the legal requirements associated with these

- Users may download and print one copy of any publication from the public portal for the purpose of private study or research.

- You may not further distribute the material or use it for any profit-making activity or commercial gain

If the publication is distributed under the terms of Article $25 \mathrm{fa}$ of the Dutch Copyright Act, indicated by the "Taverne" license above, 


\section{Impulsivity, "Advergames," and Food Intake}

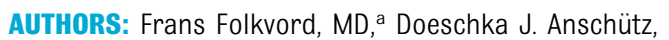

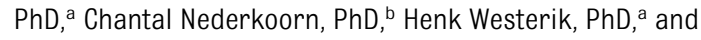
Moniek Buijzen, PhDa

a Behavioural Science Institute, Radboud University, Nijmegen, Netherlands; and ${ }^{b}$ Department of Psychology and Neuroscience, Maastricht University, Maastricht, Netherlands

\section{KEY WORDS}

food advertisements, advergames, impulsivity, caloric intake, children, obesity

\section{ABBREVIATIONS}

kcal一kilocalories

VAS-visual analogue scale

Mr Folkvord conceptualized and designed the study, collected the data, carried out the analyses, and drafted the initial manuscript; Drs Anschütz, Nederkoorn, and Westerik, and Prof Dr Buijzen conceptualized and designed the study and critically reviewed the manuscript; and all authors approved the final manuscript as submitted.

This trial has been registered with the Australian New Zealand Clinical Trials Registry (identifier ACTRN12613000035729).

www.pediatrics.org/cgi/doi/10.1542/peds.2013-3384

doi:10.1542/peds.2013-3384

Accepted for publication Feb 27, 2014

Address correspondence to Frans Folkvord, MD, Behavioural Science Institute, Radboud University Nijmegen, Thomas van Aquinostraat 2, 6526 GD Nijmegen, Netherlands. E-mail: f.folkvord@maw.ru.nl

PEDIATRICS (ISSN Numbers: Print, 0031-4005; Online, 1098-4275).

Copyright (C 2014 by the American Academy of Pediatrics

FINANCIAL DISCLOSURE: The authors have indicated they have no financial relationships relevant to this article to disclose.

FUNDING: This research was granted by the Behavioural Science Institute, Radboud University Nijmegen.

POTENTIAL CONFLICT OF INTEREST: The authors have indicated they have no potential conflicts of interest to disclose.
WHAT'S KNOWN ON THIS SUBJECT: Previous studies have shown that food advertisements influence caloric intake among children. However, individual susceptibility to food advertisements has not been examined thoroughly.

WHAT THIS STUDY ADDS: This study examines the role of impulsivity in the effect of food advertisements. An advergame promoting snacks overruled refraining from eating, especially among impulsive children. The findings suggest that impulsivity plays an important role in susceptibility to food advertisements.

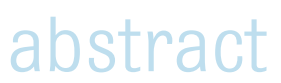

BACKGROUND AND OBJECTIVES: Previous studies have focused on the effect of food advertisements on the caloric intake of children. However, the role of individual susceptibility in this effect is unclear. The aim of this study was to examine the role of impulsivity in the effect of advergames that promote energy-dense snacks on children's snack intake.

METHODS: First, impulsivity scores were assessed with a computer task. Then a randomized between-subject design was conducted with 261 children aged 7 to 10 years who played an advergame promoting either energy-dense snacks or nonfood products. As an extra manipulation, half of the children in each condition were rewarded for refraining from eating, the other half were not. Children could eat freely while playing the game. Food intake was measured. The children then completed questionnaire measures, and were weighed and measured.

RESULTS: Overall, playing an advergame containing food cues increased general caloric intake. Furthermore, rewarding children to refrain from eating decreased their caloric intake. Finally, rewarding impulsive children to refrain from eating had no influence when they were playing an advergame promoting energy-dense snacks, whereas it did lead to reduced intake among low impulsive children and children who played nonfood advergames.

CONCLUSIONS: Playing an advergame promoting energy-dense snacks contributes to increased caloric intake in children. The advergame promoting energy-dense snacks overruled the inhibition task to refrain from eating among impulsive children, making it more difficult for them to refrain from eating. The findings suggest that impulsivity plays an important role in susceptibility to food advertisements. Pediatrics 2014;133:1007-1012 
Rates of childhood obesity have increased greatly in the past 3 decades. ${ }^{1}$ Although the causes of this trend are multifaceted, there is growing evidence that food commercials are a major contributor. ${ }^{2}$ Food consumption can be activated by salient environmental cues in an automatic and difficult to control way. ${ }^{3}$ Content analyses reveal that the majority of food products promoted are energy-dense and high in fat, sugar, and/or salt, which is in sharp contrast to (inter)national dietary guidelines. ${ }^{2}$

Cue reactivity theory states that food cues induce craving for food and actual eating behavior owing to the presence of sensory inputs associated with past consumption. ${ }^{4,5}$ The sight, smell, or thought of tasty food induces appetite, and insuffcient inhibitory control causes failure in inhibition, leading to increased food intake., 6 Impaired behavioral inhibition (ie, impulsivity) might make it more difficult for children to resist the temptation of energy-dense food. ${ }^{8,9} \mathrm{Im}$ pulsivity is generally defined as the tendency to control, think, and plan insufficiently. ${ }^{10}$ Two aspects of impulsivity can be distinguished: insufficient inhibitory behavioral control and reward sensitivity or the inability to delay reward. ${ }^{11}$ Being able to control impulsive behaviors can be an important explanation for the individual susceptibility to food advertisements, but this has not been examined before.

The objective ofthis study is to examine the role of impulsivity in the effect of advergames promoting energy-dense snacks on children's snack consumption. Advergames are online electronic games that are used to advertise a product or a brand. ${ }^{12-14}$ Online games provide a highly involving, interactive, and entertaining brand experience. ${ }^{12}$ We hypothesize that (H1) playing advergames promoting energy-dense snacks increases caloric intake, (H2a) stimulating response inhibition by rewarding refraining from eating decreases caloric intake, and (H2b) children who are rewarded for refraining from eating have a lower caloric intake when they play a nonfood advergame than when they play a food advergame. We also expect that $(\mathrm{H} 3)$ impulsive children eat more. Specifically, we expect (H4) that rewarding refraining will have less influence on high impulsive children, especially when they are playing a food advergame.

\section{METHODS}

\section{Study Design}

We used a factorial between-subject design: 2 (type of advergame: energy-dense snacks versus nonfood products) $\times 2$ (inhibition task: reward to refrain from eating versus no reward) $\times 2$ (impulsivity: high versus low). The dependent variable was caloric intake. While playing, 2 bowls of energy-dense snacks were presented: (1) jelly candy (cola bottles) and (2) milk chocolate candy shells. The jelly candy were identical to 1 of the food products shown in the advergame promoting energy-dense snacks.

We counterbalanced and randomly assigned children to 1 of 4 conditions, which involved playing 1 the energy-dense snacks advergame (ie, promoting a popular candy brand and 8 different sweets from this candy brand) without the inhibition task ${ }^{2}$; the energy-dense snacks advergame with the inhibition task ${ }^{3}$; the nonfood advergame (ie, promoting a popular Dutch toy brand and 8 individual toys from this brand) without the inhibition task ${ }^{4}$; and the nonfood advergame with the inhibition task. All games were identical, except for the advertised brands and products. The game involved an online memory game with 16 cards, whereby brand name and logos appeared on the back of the cards, and the individual products appeared on the front. These products clearly displayed the brand logos. For the candy products we used high-quality images of gummy cola bottles, bananas, cherries, frogs, licorice, and other gummy and jelly sweets. For the toys we used images of a trampoline, keyboard, basketball, teddy bear, drum kit, and other toys from this brand. Cards were laid out in a grid face down. On each turn, the child turned 1 card over, then a second. If the 2 cards matched, they remained open. If they did not match, the cards were turned back over and the child got another turn. The goal was to match the pairs of cards. When cards were turned over, it was important to remember where they were for when the matching card turned up later in the game. To enhance awareness of the brand, we showed it on the right side of the screen. To immerse the children into the game by exerting time pressure with a digital timer top-left of the screen and a time bar top-center of the screen. Furthermore, the game played an unpleasant sound when a child selected a false pair and a pleasant sound with a correct pair. The experimenter left the room every time the children played the advergame.

\section{Measures}

\section{Impulsivity}

Impulsivity is a multifaceted construct, in which roughly 2 aspects can be distinguished: reward sensitivity and insufficient inhibitory behavioral control. ${ }^{15}$ To measure impulsivity we used the door-opening task, which has been specially developed to measure reward sensitivity in young individuals, differentiating between normal children and children who have impulsive disorders like attention deficit hyperactivity disorder and conduct disorder. ${ }^{16-19}$ The experimenter told the child that the aim of the task was to earn as many points as possible. When the child opened a door revealing a yellow smiley face the child received a point, but when the door revealed a blue sad smiley face, the child lost a point. In total, there were 90 doors to open. The tasks started with a $90 \%$ 
chance of winning, which decreased with $10 \%$ after every 10 doors. The chance was therefore $50 \%$ after 40 doors, being the most profitable moment to stop the game. Children who opened more than 40 doors were considered as highly impulsive. Because the child's aim was to earn as many points as possible, he or she should quit opening doors once the probability of a winning door dropped below $50 \%$. When children continued the game, the chances of losing increased and winning decreased. If the child keeps opening doors in search for reward despite punishment, the reward system is considered dominant. ${ }^{19}$

\section{$B M I$}

We calculated BMl, measured as weight $(\mathrm{kg}) /$ height $^{2}(\mathrm{~m})$. We measured weight to the nearest $0.1 \mathrm{~kg}$ and height to the nearest $0.5 \mathrm{~cm}$ while the children were wearing clothing but no shoes. We calculated whether the children were underweight, normal weight, overweight, or obese using international cut-off scores. ${ }^{20}$

\section{Caloric Intake}

We weighed the amount of snack food that a child ate before each child entered the room and again after eating. We used a professional balance scale to estimate to the nearest $0.1 \mathrm{~g}$. We calculated the number of grams that a child ate in kilocalories (kcal) for use as a dependent measure. The amount of energy-dense snack food that a child ate was the sum of the caloric intake of jelly candy and milk chocolate candy.

\section{Hunger}

We controlled for individual differences in hunger by presenting the children with a visual analog scale (VAS; $14 \mathrm{~cm}$ ) measuring the extent to which they felt hungry before the experiment began. The anchors were "not hungry at all" and "very hungry." VAS's have been used successfully and extensively to assess subjective appetite sensations, like hunger, prospective food consumption, and fullness in children. ${ }^{14,21-23}$ Furthermore, VAS was compared with Likert scale measurements among children and found to be of comparable reliability. ${ }^{24}$

Attitude toward brand and foods shown in the advergames was assessed with 6 items (nice, stupid, tasteful, untasteful, cool, boring) on a VAS scale. This measurement has been established by Holbrook and Batra, ${ }^{25}$ and tested extensively among (young) children ${ }^{14,26}$ At the end of the experiment, we asked the children to indicate the goal of the research, but no child gave the correct answer.

\section{Subjects}

Subjects were 266 children (grades 2-3) from 5 primary schools in the Netherlands. We obtained approval from the institute's ethical committee for social sciences and obtained informed consent from the schools and parents. More than $93 \%$ of the children were allowed to participate. Data collection occurred between January 2013 and March 2013. The experimenter brought 1 child to a separate classroom containing a computer where they started with an online questionnaire to assess gender, age, and pre-experimental hunger. Subsequently the child conducted the door-opening task and after this task played 1 version of the advergames. The child was instructed that (s)he would be playing a memory game for 5 minutes and should attempt to finish as many games as possible, which were unlimited. Then the experimenter placed the bowls with food and a glass of water at the same table as the computer. The experimenter told the children without the inhibition task that (s) he could eat as much as (s)he wanted, and the children with the inhibition task that (s)he could eat as much as (s)he wanted but that if (s)he would eat nothing (s)he would get a reward afterward. Further instructions stated that after each game, the time bar would stop, and the score would appear; then the time would continue when the new game started. The child signaled the experimenter when the game stopped after 5 minutes. To give the children an opportunity to snack, the children had a small break of 30 seconds after 2 finished games before they could start the next game. Subsequently, the second part of the questionnaire was filled out and length and height were measured. The experimenter asked all children to refrain from discussing the experiment with their classmates. After all children had finished participation, they were allowed to choose a pencil as reward. The children did not receive the reward immediately after the experiment and all children got the reward. After each session, the experimenter weighed the bowls to calculate caloric intake and refilled them before the next child entered.

\section{Statistical Analysis}

Randomization checks using a 1-factor ANOVA were conducted for gender, hunger, age, BMI, impulsivity, and kcal energy intake (Table 1). Outlying scores on caloric intake were examined by computing residual scores and testing them for Mahal's distance, Cook's distance, and leverage scores, showing no indications for outlying scores. The main effects of type of advergame, impulsivity, and inhibition task were tested with analysis of covariance. An additional analysis of covariance tested the interaction effects between type of advergame, inhibition task, and impulsivity. Bonferroni-corrected post hoc test was used to examine the differences between the experimental conditions. We calculated effect sizes for Cohen's $f$ and Cohen's $d$.

\section{RESULTS}

\section{Descriptives}

The final sample consisted of 261 children, $50.2 \%$ boys. We excluded 5 children from the analyses because they had not finished the session $(n=3)$ or 
TABLE 1 Variables Measured, By Condition ${ }^{1}$

\begin{tabular}{|c|c|c|c|c|}
\hline & $\begin{array}{c}\text { Energy-Dense Snack Without } \\
\text { Inhibition Task }(n=69)\end{array}$ & $\begin{array}{l}\text { Energy-Dense Snack With } \\
\text { Inhibition Task }(n=65)\end{array}$ & $\begin{array}{c}\text { Nonfood Without Inhibition } \\
\text { Task }(n=62)\end{array}$ & $\begin{array}{c}\text { Nonfood With Inhibition } \\
\text { Task }(n=65)\end{array}$ \\
\hline Gender (boy $=1$, girl $=0$ ) & $0.55(0.5)$ & $0.43(0.5)$ & $0.47(0.5)$ & $0.54(0.5)$ \\
\hline Hunger on VAS (cm) & $2.8(3.6)$ & 3.7 (3.9) & $3.6(4.5)$ & $3.2(4.0)$ \\
\hline Age (y) & $7.8(0.8)$ & $7.8(0.7)$ & $7.7(0.7)$ & $7.6(0.7)$ \\
\hline BMI, corrected $\left(\mathrm{kg} / \mathrm{m}^{2}\right)$ & $1.25(0.4)$ & $1.29(0.5)$ & $1.16(0.4)$ & $1.29(0.5)$ \\
\hline Impulsivity & $39.3(28.9)$ & $38.8(26.2)$ & $36.9(28.5)$ & $36.9(25.5)$ \\
\hline Total energy intake (kcal) & $156.3(135.2)$ & $87.3(114.3)$ & $101.3(74.1)$ & $33.2(74.4)$ \\
\hline
\end{tabular}

teachers had interrupted $(n=2)$. In our sample, $3.8 \%$ of children were underweight, $71.3 \%$ normal weight, $18.4 \%$ overweight, and $6.5 \%$ obese.

We found no differences between the experimental conditions for gender, hunger, BMI, age, and impulsivity. Brand recognition and attitudes toward the game, striving for the reward, and how much they wanted the reward did not differ between the type of advergame.

\section{Main Analyses}

Results confirmed our first hypothesis ${ }^{1} \mathrm{H}$ showing a significant effect of type of advergame on caloric intake $(P<$ 0.01 ) (Table 2). Children who played an advergame promoting energy-dense snacks ate significantly more $(P<$ $0.01)$ than children who played an advergame promoting nonfood products. Children who were hungrier ate more $(P<0.05)$. Hypothesis H2a was also confirmed, showing a significant effect of the inhibition task on caloric intake $(P<.01)$. Children who played 1 of the advergames without the inhibition task ate more than the children who played an advergame with the inhibition task. The post hoc results confirmed $\mathrm{H} 2 \mathrm{~b}$, showing that children who played the advergame promoting energy-dense snacks with the inhibition task ate significantly more $(P<0.01)$ than the children who played the nonfood advergame with the inhibition task. Furthermore, we found that children who played the advergame promoting energy-dense snacks with the inhibition task had a lower caloric intake $(P<0.01)$ compared

TABLE 2 Results From 2 Univariate Analyses of Covariance With Total Energy Intake as a Dependent Variable $(n=261)$

\begin{tabular}{|c|c|c|}
\hline \multirow[b]{2}{*}{ Gender (boy = 1, girl =0) } & \multicolumn{2}{|c|}{ Total Energy Intake (kcal) } \\
\hline & $F(1,252)=2.043$ & $F(1,248)=1.369$ \\
\hline Hunger on VAS $(\mathrm{cm})$ & $F(1,252)=5.046^{\mathrm{a}}$ & $F(1,248)=4.375^{\mathrm{a}}$ \\
\hline Age (y) & $F(1,252)=1.310$ & $F(1,248)=1.862$ \\
\hline BMI, corrected $\left(\mathrm{kg} / \mathrm{m}^{2}\right)$ & $F(1,252)=0.786$ & $F(1,248)=0.510$ \\
\hline Advergames & $F(1,252)=18.541^{b}$ & $F(1,248)=16.162^{b}$ \\
\hline Inhibition task & $F(1,252)=31.325^{b}$ & $F(1,248)=26.439^{b}$ \\
\hline Impulsivity & $F(1,252)=2.704$ & $F(1,248)=2.206$ \\
\hline Advergame*inhibition task & & $F(1,248)=0.017$ \\
\hline Advergamesimpulsivity & & $F(1,248)=2.717$ \\
\hline Inhibition task*impulsivity & & $F(1,248)=5.932^{\mathrm{a}}$ \\
\hline Advergames*inhibition taskimpulsivity & & $F(1,248)=4.364^{\mathrm{a}}$ \\
\hline Effect size $^{\mathrm{C}}$ & 0.18 & 0.22 \\
\hline Explained variance (\%) & 17.9 & 21.1 \\
\hline
\end{tabular}

with children who played the advergame promoting energy-dense snacks without the inhibition task. Children who played the advergame promoting nonfood products with the inhibition task ate less $(P<0.01)$ than children who played the nonfood advergame without the inhibition task. In contrast with $\mathrm{H} 3$, which stated that impulsive children would eat more, we found no effect for impulsivity $(P>0.05)$.

Finally, we expected ( $\mathrm{H} 4$ ) that rewarding refraining would have less influence on high impulsive children, particularly when they were playing an advergame promoting energy-dense snacks. Results showed that the 3-way interaction was significant $(P<0.05)$, shown in Table 2. Bonferroni corrected post hoc test (Table 3) showed that there was no difference for general caloric intake $(P>.05)$ between the high impulsive children who played the advergame promoting energydense snacks with the inhibition task compared with the children without the inhibition task. In contrast, results showed that impulsive children who played the advergame promoting nonfood products with the inhibition task had a significantly lower caloric intake $(P<0.05)$ than those without the inhibition task. Low impulsive children who played the advergame promoting energy-dense snacks with the inhibition task had a significantly lower caloric intake $(P<.01)$ than those without the inhibition task. Finally, low impulsive children who played the advergame promoting nonfood products with the inhibition task had a lower caloric intake $(P<.01)$ than the children who did not have this inhibition task.

\section{DISCUSSION}

This is the first study examining the role of impulsivity in the effect of food advertisements on actual snack intake 
TABLE 3 Adjusted Means and SDs of Food Intake (in kcal) Controlled for Gender, Hunger, and Age, By Condition and Impulsivity ( $n=261$ )

\begin{tabular}{|c|c|c|c|c|c|c|}
\hline & \multicolumn{2}{|c|}{ Low Impulsivity ${ }^{a}$} & & \multicolumn{2}{|c|}{ High Impulsivity ${ }^{\mathrm{b}}$} & \\
\hline & No Inhibition Task & With Inhibition Task & & No Inhibition Task & With Inhibition Task & \\
\hline Advergame promoting energy-dense snack & $203.0^{\star} \pm 16.4(n=37)$ & $76.7 \dagger \pm 16.0(n=39)$ & $P<.001$ & $104.6^{\star} \pm 18.1(n=31)$ & $94.6 \dagger \pm 19.9(n=26)$ & $P>.05$ \\
\hline Advergame promoting nonfood products & $101.9+ \pm 15.9(n=40)$ & $32.4 \S \pm 15.5(n=42)$ & $P<.001$ & $99.4 \div \pm 21.4(n=23)$ & $39.2 \S \pm 21.0(n=23)$ & $P<.05$ \\
\hline
\end{tabular}

among young children. We found that food cues in advergames triggered eating behavior and that rewarding children to refrain from eating decreased caloric intake in both types of advergames, thereby supporting hypotheses 1 and 2a. From the children who were rewarded, children who played the food advergame ate more than the children who played the nonfood advergame, confirming hypothesis $2 b$. Impulsive children did not eat more than less impulsive children, which refutes hypothesis 3 . Finally, we found that rewarding children to refrain from eating had less influence on high impulsive children than on low impulsive children, especially when they were playing an advergame promoting energy-dense snacks, supporting hypothesis 4 . These findings imply that impulsive children have difficulties self-regulating their caloric intake during a food advertisement when they are rewarded to refrain from eating, but not when they are facing a nonfood advertisement. Furthermore, we found that less impulsive children had a lower caloric intake when they were rewarded to refrain from eating in both type of advergames. These latter findings mark the individual susceptibility to food advertising, which is a very interesting insight.

Cue reactivity theory states that foodrelated cues (eg, the sight or smell of food) act as conditioned stimuli that trigger conditioned responses, like craving and actual eating behavior. ${ }^{4}$ This may mean that exposure to foodrelated cues results in cephalic phase responses and strong desires to eat, preparing children for food intake. In- creased impulsivity might make it more difficult for children to resist the temptation of energy-dense food when craving for food is elicited by food commercials. This reasoning is in line with our hypotheses and earlier findings. $8,27,28$ A remarkable finding was that low impulsive children playing the energy-dense advergame ate more than high impulsive children playing the same game when they were not asked to refrain from eating. A possible explanation is that conducting subsequent tasks may have led to a state of ego depletion. The high impulsive children did not inhibit their responses during the impulsivity task to the same extent as the low impulsive children. The latter were more successful in inhibiting their responses during the impulsivity task. Consequently, after successfully controlling reward sensitivity during the impulsivity task, a decrease in self-control could have occurred among the low impulsive children. ${ }^{29}$

Besides the large sample size, a strength of this study is its high external validity, as the advergames used are identical or comparable to advergames used by many (food) companies. Advergames are interactive entertainment, which makes it more difficult for children to recognize commercial message in the game. Because cognitive capacity is directed to playing the game, there is not enough capacity to think critically about the purpose of the game.30 Moreover, we were able to test a large number of children and we successfully manipulated response inhibition so that we could conduct adequate analyses to examine the role of self-regulation when stimulated to inhibit responses during a food commercial.

\section{CONCLUSIONS}

This study showed that exposure to food cues in advergames influences caloric intake and that these food cues hamper self-regulation when young children are rewarded to refrain from eating. Children who played the advergame promoting energy-dense snacks did not report less motivation to self-regulate response inhibition, so an explanation could be that the food cues in the advergame signaled food intake, which led to failures in selfregulation of snack intake. Furthermore, impulsive children showed more difficulties in refraining from eating while playing an advergame promoting energydense snacks, supporting concerns from scholars that food commercials contribute to vulnerable children's snacking. ${ }^{13}$ Future research should focus on whether children can be tutored by their parents to self-regulate their snack intake during or after advertising exposure. Active advertising-related parenting training children to cope with persuasive intentions of food advertisements can reduce undesired advertising effects. ${ }^{31}$ Studies have shown that training self-regulation to control impulses for food is successful in learning adolescents and adults to control their food intake after temptations and tempting snacks, 32,33 so we might expect that children can also be trained to selfregulate their snack intake. A final recommendation to parents is reducing the availability of snack foods at home. 


\section{REFERENCES}

1. Han JC, Lawlor DA, Kimm SYS. Childhood obesity. Lancet. 2010;375(9727):1737-1748

2. World Health Organization. WHO Report on Diet, Nutrition and the Prevention of Chronic Disease. Joint WHO/FAO Expert Consultation WHO Technical Report Series. Geneva, Switzerland: World Health Organization; 2003

3. Cohen DA. Neurophysiological pathways to obesity: below awareness and beyond in dividual control. Diabetes. 2008;57(7):17681773

4. Coelho JS, Jansen A, Roefs A, Nederkoorn C. Eating behavior in response to food-cue exposure: examining the cue-reactivity and counteractive-control models. Psychol Addict Behav. 2009;23(1):131-139

5. Jansen A. A learning model of binge eating: cue reactivity and cue exposure. Behav Res Ther. 1998;36(3):257-272

6. Jansen A, Nederkoorn C, van Baak L, Keirse C, Guerrieri R, Havermans R. High-restrained eaters only overeat when they are also impulsive. Behav Res Ther. 2009;47 (2):105-110

7. Hofmann W, Malte F, Roefs A. Three ways to resist temptation: the independent contributions of executive attention, inhibitory control, and affect regulation to the impulse control of eating behavior. J Exp Soc Psychol. 2009;45:431-435

8. Nederkoorn C, Guerrieri R, Havermans RC, Roefs A, Jansen A. The interactive effect of hunger and impulsivity on food intake and purchase in a virtual supermarket. Int $J$ Obes (Lond). 2009;33(8):905-912

9. Lawrence NS, Hinton EC, Parkinson JA, Lawrence AD. Nucleus accumbens response to food cues predicts subsequent snack consumption in women and increased body mass index in those with reduced self-control. Neuroimage. 2012;63(1):415-422

10. Solanto MV, Abikoff H, Sonuga-Barke E, et al. The ecological validity of delay aversion and response inhibition as measures of impulsivity in AD/HD: a supplement to the NIMH multimodal treatment study of AD/HD. J Abnorm Child Psychol. 2001;29(3): 215-228

11. Dougherty DM, Mathias CW, Marsh DM, Jagar AA. Laboratory behavioral measures of impulsivity. Behav Res Methods. 2005;37 (1):82-90

12. Culp J, Bell RA, Cassady D. Characteristics of food industry web sites and "adver- games" targeting children. J Nutr Educ Behav. 2010;42(3):197-201

13. Nairn A, Hang H. Advergames: it's not child's play. A review of research. Family and parenting institute 2012. Available at: www. agnesnairn.co.uk/policy_reports/advergamesits-not-childs-play.pdf. Accessed June 28, 2013

14. Folkvord F, Anschütz DJ, Buijzen M, Valkenburg PM. The effect of playing advergames that promote energy-dense snacks or fruit on actual food intake among children. Am J Clin Nutr. 2013;97 (2):239-245

15. Guerrieri R, Nederkoorn C, Jansen A. The interaction between impulsivity and a varied food environment: its influence on food intake and overweight. Int J Obes. 2008;32 (4):708-714

16. Daugherty TK, Quay HC. Response perseveration and delayed responding in childhood behavior disorders. J Child Psychol Psychiatry. 1991;32(3):453-461

17. Matthys W, van Goozen SHM, de Vries H, Cohen-Kettenis PT, van Engeland $H$. The dominance of behavioural activation over behavioural inhibition in conduct disordered boys with or without attention deficit hyperactivity disorder. I Child Psychol Psychiatry. 1998;39(5):643-651

18. Shapiro SK, Quay HC, Hogan AE, Schwartz KP. Response perseveration and delayed responding in undersocialized aggressive conduct disorder. J Abnorm Psychol. 1988; 97(3):371-373

19. Nederkoorn C, Braet C, Van Eijs Y, Tanghe A, Jansen $A$. Why obese children cannot resist food: the role of impulsivity. Eat Behav. 2006; (4):315-322

20. Cole TJ, Bellizzi MC, Flegal KM, Dietz WH. Establishing a standard definition for child overweight and obesity worldwide: international survey. BMJ. 2000;320(7244): 1240-1243

21. Dodd CJ, Welsman JR, Armstrong N. Energy intake and appetite following exercise in lean and overweight girls. Appetite. 2008;51 (3):482-488

22. Moore MS, Dodd CJ, Welsman JR, Armstrong $N$. Short-term appetite and energy intake following imposed exercise in 9- to 10-yearold girls. Appetite. 2004;43(2):127-134

23. Rumbold PLS, Dodd-Reynolds CJ, Stevenson E. Agreement between paper and pen vi- sual analogue scales and a wristwatchbased electronic appetite rating system (PR0-Diary(C), for continuous monitoring of free-living subjective appetite sensations in 7-10 year old children. Appetite. 2013;69: 180-185

24. van Laerhoven $\mathrm{H}$, van der Zaag-Loonen $\mathrm{HJ}$, Derkx BH. A comparison of Likert scale and visual analogue scales as response options in children's questionnaires. Acta Paediatr. 2004;93(6):830-835

25. Holbrook MB, Batra R. Assessing the role of emotions as mediators of consumer responses to advertising. J Consum Res. 1987; 14(3):404-420

26. Panic $K$, Cauberghe V, de Pelsmacker P. Comparing TV ads and advergames targeting children: the impact of persuasion knowledge on behavioral responses. $J A d$ vert. 2013;42(2-3):264-273

27. Jasinska AJ, Yasuda M, Burant CF, et al. Impulsivity and inhibitory control deficits are associated with unhealthy eating in young adults. Appetite. 2012;59(3):738747

28. Francis LA, Susman EJ. Self-regulation and rapid weight gain in children from age 3 to 12 years. Arch Pediatr Adolesc Med. 2009; 163(4):297-302

29. Baumeister RF. Yielding to temptation: selfcontrol failure, impulsive purchasing, and consumer behavior. J Consum Res. 2002;28 (4):670-676

30. Rozendaal E, Lapierre MA, van Reijmersdal EA, Buijzen M. Reconsidering advertising literacy as a defense against advertising effects. Media Psychol. 2011;14(4):333354

31. Buijzen M. The effectiveness of parental communication in modifying the relation between food advertising and children's consumption behaviour. Br J Dev Psychol. 2009;27 (Pt 1):105-121

32. Kroese FM, Adriaanse MA, Evers C, De Ridder DTD. "Instant success": turning temptations into cues for goal-directed behavior. Pers Soc Psychol Bull. 2011;37(10):13891397

33. de Ridder D, de Vet M, Stok M, Adriaanse $M$, de Wit J. Obesity, overconsumption and self-regulation failure: the unsung role of eating appropriateness standards. Health Psych Rev. 2013;7(2):146-165 


\section{Impulsivity, "Advergames," and Food Intake}

Frans Folkvord, Doeschka J. Anschütz, Chantal Nederkoorn, Henk Westerik and Moniek Buijzen

Pediatrics 2014;133;1007

DOI: 10.1542/peds.2013-3384 originally published online May 5, 2014;

\begin{tabular}{|c|c|}
\hline $\begin{array}{l}\text { Updated Information \& } \\
\text { Services }\end{array}$ & $\begin{array}{l}\text { including high resolution figures, can be found at: } \\
\text { http://pediatrics.aappublications.org/content/133/6/1007 }\end{array}$ \\
\hline References & $\begin{array}{l}\text { This article cites } 31 \text { articles, } 3 \text { of which you can access for free at: } \\
\text { http://pediatrics.aappublications.org/content/133/6/1007\#BIBL }\end{array}$ \\
\hline Subspecialty Collections & $\begin{array}{l}\text { This article, along with others on similar topics, appears in the } \\
\text { following collection(s): } \\
\text { Media } \\
\text { http://www.aappublications.org/cgi/collection/media_sub } \\
\text { Nutrition } \\
\text { http://www.aappublications.org/cgi/collection/nutrition_sub } \\
\text { Obesity } \\
\text { http://www.aappublications.org/cgi/collection/obesity_new_sub }\end{array}$ \\
\hline Permissions \& Licensing & $\begin{array}{l}\text { Information about reproducing this article in parts (figures, tables) or } \\
\text { in its entirety can be found online at: } \\
\text { http://www.aappublications.org/site/misc/Permissions.xhtml }\end{array}$ \\
\hline Reprints & $\begin{array}{l}\text { Information about ordering reprints can be found online: } \\
\text { http://www.aappublications.org/site/misc/reprints.xhtml }\end{array}$ \\
\hline
\end{tabular}

http://www.aappublications.org/site/misc/reprints.xhtml

\section{American Academy of Pediatrics}




\section{PED I ATR I C S}

OFFICIAL JOURNAL OF THE AMERICAN ACADEMY OF PEDIATRICS

\section{Impulsivity, "Advergames," and Food Intake}

Frans Folkvord, Doeschka J. Anschütz, Chantal Nederkoorn, Henk Westerik and Moniek Buijzen

Pediatrics 2014;133;1007

DOI: 10.1542/peds.2013-3384 originally published online May 5, 2014;

The online version of this article, along with updated information and services, is located on the World Wide Web at:

http://pediatrics.aappublications.org/content/133/6/1007

Pediatrics is the official journal of the American Academy of Pediatrics. A monthly publication, it has been published continuously since 1948. Pediatrics is owned, published, and trademarked by the American Academy of Pediatrics, 345 Park Avenue, Itasca, Illinois, 60143. Copyright @ 2014 by the American Academy of Pediatrics. All rights reserved. Print ISSN: 1073-0397.

\section{American Academy of Pediatrics}

